\title{
De los cruces entre el cine y la literatura: Osvaldo Soriano y la desmitificación del Olimpo hollywoodense
}

\section{Roberta Previtera \\ UNIVERSITE PARIS-SORBONNE·robiprevi@hotmail.it}

Ha estudiado literatura española e hispanoamericana en la Universidad Federico II de Nápoles, en la Universidad Complutense de Madrid y en la Universidad La Sapienza de Roma. Desde 2010 prepara una tesis doctoral sobre la presencia del cine en la narrativa argentina contemporánea en la Universidad Paris-Sorbonne y enseña literatura española e hispanoamericana en la Universidad Lille 3. Entre sus publicaciones se encuentran diversos artículos sobre la obra de Bioy Casares, Di Benedetto, Soriano, Pauls y Portela en revistas internacionales arbitradas y diversas traducciones al italiano de cuentos hispanoamericanos contemporáneos.

RECIBIDO: 31 DE MAYO DE 2013

ACEPTADO: 2 DE SEPTIEMBRE DE 2013

\begin{abstract}
Resumen: Este artículo se propone investigar la recuperación del discurso cinematográfico operada por el escritor argentino Osvaldo Soriano. El autor retoma personajes arquetípicos, esquemas narrativos y convenciones descriptivas de los principales géneros cinematográficos hollywoodenses y las adapta al contexto cultural argentino. En particular se analizará la relación que se establece entre la novela Cuarteles de invierno y el género western. Se trata de una rescritura paródica en la que Soriano, desmitificando los valores tradicionalmente asociados al género, transmite un punto de vista crítico sobre el presente histórico.
\end{abstract}

Palabras Clave:Soriano, desmitificación, cine, western, reescritura.
Abstract: The aim of the work is studying how Osvaldo Soriano introduces elements of cinematographic speech in his novels. He picks up Hollywood archetypical characters, narrative formulas and descriptive conventions and adapts them to the Argentinean cultural context. In particular we will analyze the relationship between the novel Cuarteles de invierno and the western. This novel is a parody where Soriano operate a demystification of the genre's values in order to transmit a critical evaluation of the contemporary society.

Key Words: Soriano, demystification, cinema, western, rewriting. 
Este trabajo se propone analizar la recuperación del discurso cinematográfico operada por el escritor argentino Osvaldo Soriano, cuyas novelas presentan una reescritura de convenciones narrativas y descriptivas típicas del cine de género hollywoodense. En una primera parte, tras recordar el estatuto eminentemente discursivo del cine, nos centraremos en la cuestión de los géneros cinematográficos y en el poder ideológico y mitificador que estos últimos han tenido a lo largo del siglo XX. En una segunda parte, estudiaremos la presencia del cine de género en la narrativa de Soriano y, haciendo referencia a varias de sus obras, intentaremos dar cuenta de su voluntad de experimentar con los grandes géneros del cine hollywoodense. En una tercera, nos centraremos en dos novelas de los años ochenta: No habrá más penas ni olvidos y Cuarteles de Invierno y estudiaremos su relación con el cine western. En fin, en la cuarta y última parte avanzaremos unas hipótesis acerca de las finalidades que esta reescritura puede tener en el contexto de la Argentina de los años ochenta.

\section{Los géneros cinematográficos como generadores de mitologías contemporáneas}

La idea de considerar el cine como un tipo de discurso ha sido ampliamente debatida por la teoría cinematográfica, que ha recuperado con frecuencia muchas herramientas analíticas de la lingüística y de la teoría literaria.

La definición de filme como discurso está estrictamente vinculada al concepto de énonciation ${ }^{1}$ propuesto por Emile Benveniste ${ }^{2}$. En un artículo de 1976, Christian Metz afirma que el filme puede ser considerado como discurso solo "si on le réfère aux intentions du cinéaste, aux influences qu'il exerce sur le public, etc. ; mais le propre de ce discours-là, et le principe même de son efficace comme discours, est justement d'effacer les marques d'énonciation et de se déguiser en histoire" (Metz, 1976: 113). Unos años después Francesco Casetti hablará de la "discursividad" como rasgo constitutivo del texto fílmico:

Ce qui marque le texte filmique comme tel, c'est [...] le fait qu'en lui se rencontrant les intentions d’un émetteur et les attentes d'un récepteur [...]. On peut dire, plus synthétiquement et plus précisément, qu'un texte filmique est un

\footnotetext{
${ }^{1}$ Robert Stam define así el concepto de "énonciation" en el ámbito de las teorías cinematográficas: "In film theory, enunciation has also come to signify the constitution of the subjectivity in language, and secondarily, the production and control of subject relations through the imaginary link established between the narrator and the spectator by way of their mutual investment in the discourse of the film" (Stam, 1992:105).

2 Tras distinguir entre el "enunciado", considerado como acto de habla en sí, y la "enunciación", es decir la realización individual de este acto, Benveniste llama "discursos" a todos aquellos mensajes en donde se pueden descubrir trazas de la presencia del hablante. Los mensajes donde estas trazas no aparecen son definidos en cambio como "historias" (Benveniste, 1974: 179-187 y 1977: 82-91).
} 
ensemble discursif cohérent et achevé, à travers lequel se réalisent des stratégies de communication (Casetti, 1980: 53).

Desde sus albores el cine se ha destacado por ser un canal privilegiado para la transmisión de discursos, esto se debe, muy probablemente, al estatuto particular que caracteriza el lenguaje cinematográfico frente a otros tipos de lenguajes. Como afirma Rojas Mix: "De un lado la palabra desarrolla el pensamiento analítico, ligándolo a la linealidad del lenguaje; de otro, el lenguaje visual guarda la funcionalidad del pensamiento mítico, uniéndose al gesto, que estuvo en el origen del pensamiento visual [...]" (Rojas Mix, 2006: 39). El cine produce imágenes que se depositan directamente en el inconsciente del espectador, esta propiedad lo convierte en un vehículo de modelos de pensamiento. De acuerdo con Barthes:

Tous les matériaux du mythe, qu'ils soient représentatifs ou graphiques, présupposent une conscience signifiante, que l'on peut raisonner sur eux indépendamment de leur matière. Cette matière n'est pas indifférente: L’image est, certes, plus impérative que l'écriture, elle impose la signification d'un coup, sans l'analyser, sans la disperser (Barthes, 1970: 195).

El enorme potencial comunicativo del cine es debido también al "efecto de realidad" que poseen las imágenes cinematográficas. Se cuenta que delante de la imagen de un tren que avanzaba velozmente hacia el punto de toma, los primeros espectadores huyeron del cine aterrorizados, temiendo que la locomotora saliera de la pantalla. Esta anécdota, que hoy en día nos roba una sonrisa, es reveladora de la increíble capacidad mimética que desde sus albores ha caracterizado al cine frente a las otras artes. Este potencial es particularmente evidente en el cine "espectáculo"3. De acuerdo con Pezzella: "Si el cine crítico expresivo tiende a exhibir la imagen como imagen y la apariencia como apariencia, solicitando la participación crítica del espectador, el cine espectáculo, enseña la apariencia en cuanto 'realidad', atenuando hasta el límite de lo posible la diferencia entre 'ficción' y 'realidad"' (Pezzella, 2004: 32).

Durante la proyección cinematográfica el espectador experimenta una especie de regresión de la conciencia, favorecida también por las condiciones mismas en las que se verifica la experiencia: la oscuridad de la sala, la soledad de la visión ya que tenemos la

\footnotetext{
${ }^{3}$ Pezzella en su Estética del cine distingue entre un cine comercial que él define como "cine espectáculo" y un cine "crítico-expresivo". "En el cine comercial, por lo demás, las imágenes no hacen otra cosa más que acompañar el desarrollo del suceso narrado; en el cine crítico expresivo, por el contrario, las imágenes consiguen tener su propio significado y una profundidad relativamente independiente de la imagen misma" (Pezzella, 2004: 12). Retomo la separación entre los dos tipos de cine propuesta por Pezzella, aclarando, sin embargo, que esta última no encubre ningún juicio de valor respecto al "cine comercial" o "cine de género", ya que considero que este cine, a la par del otro, ha producido un número enorme de obras maestras.
} 
tendencia a olvidar la presencia del otro, el silencio que hay (o al menos debería haber) en la sala. De hecho, la proyección se configura como una especie de ceremonia en la que el espectador tiene un rol casi pasivo. Como afirma Metz en Cine y psicoanálisis:

La institución cinematográfica prescribe un espectador inmóvil y silencioso, un espectador desposeído, constantemente en estado de baja motricidad y sobrepercepción, un espectador alienado y feliz [...] un espectador que no se recupera como sujeto hasta el último momento, mediante una identificación paradójica con la propia persona, diluida en la pura mirada (Metz, 1977: 44-45).

Esta reflexión sobre el cine como productor de discursos se combina, en el caso del cine hollywoodense, con aquella sobre los géneros cinematográficos. Durante mucho tiempo la cuestión genérica ha sido descuidada por la teoría cinematográfica. Según José Antonio Pérez Bowie esta falta de interés ha dependido del hecho de que los géneros han sido considerados durante mucho tiempo solo como "mecanismos de producción en serie" que permitían la supervivencia de la industria cultural. Además, es cierto que las teorías en torno al "cine de autor", al subestimar las películas de género considerándolas indignas de interés artístico, han contribuido a determinar este déficit de reflexión teórica (Pérez Bowie, 2008: 93). Habrá que esperar hasta los años 60 para que la discusión sobre los géneros cinematográficos empiece a cobrar peso dentro de la teoría cinematográfica. Como señala Rick Altman dos posiciones contrapuestas se perfilan ante la cuestión genérica: la primera heredera de la antropología y especialmente de las teorías de Levi-Strauss- es de tipo mítico-ritual y, "siguiendo el ejemplo de la narrativa primitiva o del folclore, [...] considera que el público es el creador de los géneros, cuya función, a su vez, es justificar y organizar una sociedad prácticamente intemporal" (Altman, 2000: 50). De acuerdo con este enfoque, los esquemas narrativos de los textos genéricos son representaciones de prácticas sociales ya existentes y funcionan como superación imaginativa de las contradicciones inherentes a dichas prácticas. Esta es, por ejemplo, la posición de Stuart Kaminski, quien, en su trabajo American film genres de 1994, al referirse al western, sostiene que los temas y problemas que presenta un género son los mismos que encarnaron los mitos más antiguos ${ }^{4}$ : los enfrentamientos bien/mal, individuo/comunidad, deseo/ley, etc. En el género se manifiesta la necesidad de encontrar un equilibrio entre los dos términos del dilema (Kaminski, 1994).

\footnotetext{
${ }^{4}$ De hecho, lo que parece problemático de la lectura mítico-ritual de los géneros es que esta los desvincule del contexto histórico considerándolos como construcciones atemporales. Sin embargo, si consideramos el mito en la acepción propuesta por Roland Barthes de "forma" veremos como este, al haber sido vaciado de su contenido originario, se puede llenar con contenidos diferentes a lo largo de la historia (Barthes, 1970: 199-200).
} 
La segunda aproximación es de tipo ideológico y encuentra su fundamento en las teorías de Althusser. Esta segunda lectura se basa en un modelo narrativo totalmente distinto y llega a unas conclusiones radicalmente divergentes de las obtenidas por la aproximación ritual. "Al concebir los textos narrativos como el vehículo que un gobierno utiliza para dirigirse a sus ciudadanos/sujetos o que una industria emplea para atraer a sus clientes, esta lectura atribuye, en consecuencia, mayor importancia a las cuestiones discursivas" (Altman, 2000: 51). Los teóricos de orientación ideológica consideran los géneros como instrumentos de control social, utilizados para imponer desde el poder una determinada ideología. Según Huerta Floriano las películas de género, como productos de masa, tendrían una función "narcótica" sobre la sociedad: "las inverosímiles soluciones que tales productos proporcionan a los conflictos disminuyen la conciencia que los espectadores tienen de los mismos y son fácilmente aceptadas evitando la rebelión [...] frente a los poderes dominantes" (Huerta Floriano, 2005: 50-51).

A partir de los años ochenta se empiezan a elaborar teorías que intentan fundir estas dos posiciones en una teoría orgánica, entre ellas destaca la de Rick Altman que -a partir de un enfoque semántico-sintáctico- afirma:

The development of a specific syntax within a given semantic context thus serves a double function: it binds element to element in a logical order, at the same time accommodating audience desires to studio concerns. The successful genre owes its success not alone to its reflection of an audience ideal, nor solely to its status as apology for the Hollywood enterprise, but to its ability to carry out both functions simultaneously. It is this sleight of hand, this strategic over determination that most clearly characterizes American film production during the studio years (Altman, 1984: 15).

Partiendo de estas afirmaciones podríamos decir que, por un lado, los géneros representan los conflictos del ser humano en una comunidad dada, y por el otro, que estas representaciones con frecuencia están guiadas por centros de poder. En este sentido el cine de género se comporta de forma parecida al mito ya que ofrece una versión esquemática, a menudo maniquea, de la realidad a la que se refiere y, gracias a la repetición de ciertos elementos en distintas producciones, contribuye a consolidar una particular visión del mundo.

Para concluir cabe señalar que el cine de género no solo es investido de un poder mitificador sino puede operar también en sentido contrario marcando la crisis de un sistema de valores. Su papel es doble: si, por una parte, puede reforzar modelos de pensamiento, por la otra, puede contribuir a acelerar su decadencia, cuando estos ya no resulten aplicables en el contexto de recepción. La desmitificación, tanto en el cine como en 
la literatura, pasa por la alteración, la reescritura, la parodia. Esta operación aparece claramente en aquellas películas que, al alterar los arquetipos de un género, hacen explotar sus convenciones desde adentro, desmitificando los valores a los que el género estaba tradicionalmente asociado. Valgan como ejemplo dos películas emblemáticas: Cabalgata infernal (1980), de Walter Hill, y Sin perdón (1992) de Clint Eastwood que operan una reescritura del héroe del género western.

\section{La narrativa de Soriano y sus usos de los géneros cinematográficos}

En la narrativa de Soriano la desmitificación se realiza a través del pasaje de un arte al otro. La suya es una "transdesmitificación" en la que discurso cinematográfico y discurso literario se cruzan en el encaje textual. Soriano se apropia de los arquetipos consolidados por los géneros hollywoodenses y, al insertarlos en su narrativa, los ridiculiza desmontando los mitos a los que estos estaban asociados. Su operación no solo afecta a los personajes, sino también a los esquemas de la acción y a la iconografía asociada al género. En otros trabajos $^{5}$ he mostrado cómo Soriano recupera también elementos del cine negro, del cine de espionaje, de la comedia slapstick y del roadmovie, retomo aquí algunas de las tesis presentadas en ellos.

En su ensayo La parodia en la nueva novela hispanoamericana 1960-1985 de 1991 Elzbieta Sklodowska señala cómo en Triste, solitario y final, la primera novela del autor, dos grandes mitos de la cultura de masa -la novela negra y el cine de Hollywood- "quedan desenmascarados tan solo para revelar la dimensión humana de sus héroes, la soledad, el desengaño y la miseria del detective Marlowe y de los cómicos Stan Laurel y Oliver Hardy [...] (Sklodowska, 1991: 135). Dos términos se imponen a la hora de analizar las novelas de Soriano: desmitificación y parodia. ¿Cuáles son las estrategias narrativas utilizadas para desmitificar al héroe del cine negro? Soriano nos presenta un Marlowe envejecido, que tras haber sido dejado por su mujer se ha vuelto débil y ha sido olvidado por todos. Ya no tiene plata, ni siquiera para comprar cigarrillos y ha tenido que vender su auto. La falta del auto, en esta, y como veremos más adelante, también en otras novelas de Soriano, asume un valor simbólico. Si en todas las películas del cine negro - The falcon takes over (1942) con George Sanders, The big sleep (1946) con Humphrey Bogart, Lady in the lake (1947) (dirigida e interpretada por Robert Montgomery), la más reciente The long goodbye (1973) de Robert Altman o las películas interpretadas por Robert Mitchum Farewell my lovely de 1975 y The big sleep (1978) -Marlowe siempre tiene auto propio, el de Triste, solitario y final, en cambio, depende del transporte público. Mientras el Marlowe de

\footnotetext{
${ }^{5}$ Véase Roberta Previtera (en prensa y 2013).
} 
Chandler ama los autos veloces, especialmente los Chryslers, para el de la novela -como destaca también José Delgado-Costa- la única posibilidad de estar dentro de un Chrysler es alquilarlo junto con un chofer hispano que le asegura que "Es un buen auto" (Soriano, 2000: 96).

Otro género revisitado por el autor es el cine de espionaje que constituye el modelo central de El ojo de la patria y que de manera tangencial había ya aparecido en la novela anterior, A sus plantas rendido un león, a través del personaje del espía francés Jean Bouvard. En ambos textos aparecen unos personajes que son caricaturas de los investigadores secretos del spy movie. mientras estos últimos tienen un claro sentido del deber y en ningún momento cometen deslices o equivocaciones, los espías de Soriano, como señala Adriana Spahr, "son indefectibles perdedores que siempre caen en los errores más pueriles y que, como el aficionado más deficiente, se debaten en la persecución de pistas falsas" (Spahr, 2006: 154). En El ojo de la patria la elección del nombre del protagonista, Julio Carré, al configurarse como una referencia al escritor John le Carré, célebre autor de spy novels, sitúa al protagonista en la tradición de los agentes secretos que desde los años sesenta habían poblado el imaginario colectivo. Estos agentes -incorruptibles ejemplos de fidelidad a la patria (británica en la mayoría de los casos) - se establecían como defensores del bien en el universo maniqueo de la Guerra Fría. El ejemplo más conocido es el célebre agente $\mathrm{OO} 7$ nacido de la pluma de Ian Fleming y convertido rápidamente en una figura clave del cine comercial de la segunda mitad del siglo XX. Julio Carré, aun inspirándose de este modelo, ha perdido el aura mítica que caracterizaba a los varios James Bond de la literatura y del cine. El personaje de Soriano es un señor de mediana edad que sufre de varices y que "durante toda su vida había pasado desapercibido y, al fin sin proponérselo, de esa filosofía hizo su profesión" (Soriano, 1992: 12). A diferencia de sus heroicos predecesores, se pasa la vida inventándose fantasiosas misiones para eludir el aburrimiento y trabaja para un jefe paranoico que está convencido de que la caída del muro de Berlín ha sido "una inmensa patraña de los rojos para dar el golpe definitivo contra el mundo libre" (Soriano, 1992: 26). En esta novela la principal estrategia utilizada por Soriano para desmitificar a su héroe, es la alteración del contexto histórico. Terminada la Guerra Fría, las operaciones de Carré resultan anacrónicas y, por lo tanto ridículas. De acuerdo con Spahr, Julio Carré y su primo hermano Jean Bouvard retoman muchas características del héroe de la serie televisiva Get Smart conocida en español con el nombre de Super Agente 86 (Spahr, 2006: 156). Se podría añadir que personajes parecidos aparecen también en célebres películas de los años 60 como Dr. Strangelove (1964) de Stanley Kubrick y sobre todo What's up, tiger Lily? (1966) de Woody Allen.

En Una sombra ya pronto serás, en fin, el modelo genérico es el del road movie. Aquí lo que está desmitificado es el arquetipo del héroe en búsqueda de aventuras ya que 
en la novela de Soriano el viaje del protagonista carece de motivaciones. En el road movie los protagonistas emprenden su viaje por distintas razones: algunos solo están animados por una sed de nuevas experiencias, que los lleva a alejarse de su casa para conocer el mundo. Es el caso, por ejemplo, de los protagonistas de Easy Rider (1969). Otros huyen de las autoridades porque están acusados de haber cometido algún crimen, como en el caso de Bonnie and Clyde (1967) o de Thelma and Louise (1991). El protagonista de la novela de Soriano, a diferencia de estos personajes, solo busca a alguien que lo acerque hasta la siguiente rotonda. Su viaje no tiene meta y cuando le preguntan a dónde va, la única respuesta que es capaz de dar es: "yo estoy de paso" (Soriano, 1994: 99). Esta carencia de una meta está confirmada por las palabras de Nadia, una clarividente que le echa las cartas en un motel, y que le dice: "usted no va a ninguna parte" (Soriano, 1994: 59). Como en el caso del cine negro y del cine de espionaje, el héroe del road movie es privado por Soriano de todos los atributos que le conferían su aura mítica: in primis del vehículo. El protagonista de Soriano no solo -como el Philip Marlowe de Triste, solitario y final- no tiene auto propio, sino que todos los autos a los que se sube en su viaje son cacharros viejos en los que no se puede ni siquiera poner la cuarta. Del Renault Gordini de Coluccini, su compañero de desventuras, se dice "tenía la carrocería llena de parches" (Soriano, 1994: 14), "el motor regulaba con un ruído de bielas cascadas" (Soriano, 1994: 15), "dos veces quiso poner la cuarta pero el cambio saltó con un ruido de bolilleros masacrados" (Soriano, 1994: 142). A través de descripciones como estas, Soriano marca una distancia entre su narrativa y el modelo original, operando al mismo tiempo una desmitificación de los mitos asociados al género. En este caso, el automóvil, la modernidad, la libertad.

\section{Reescritura del western en No habrá más penas ni olvido y Cuarteles de invierno: desmitificación del género}

No habrá más penas ni olvido (1978) es la segunda novela de Soriano. La acción se desarrolla en la Argentina, en el pueblo imaginario de Colonia Vela, pueblo que volverá a aparecer también en otras novelas posteriores, volviéndose una constante de la narrativa de Soriano. El cambio de ambientación respecto a la primera novela Triste, solitario y final que se desarrollaba en los Estados Unidos y el hecho de que la obra se publique fuera de Argentina hacen que las referencias históricas sean aquí mucho más explícitas. No habrá más penas ni olvido recrea las luchas intestinas dentro del bando peronista durante el último mandato presidencial de Juan Domingo Perón. La novela se abre in media res con un diálogo en el que se le pide al delegado municipal peronista Ignacio Fuentes que despida al empleado Mateo Gustavino por ser un "infiltrado comunista". La acusación llega de Suprino, el delegado del partido, quien se propone desestabilizar el gobierno del pueblo con el apoyo del comisario Llanos. Ignacio, al entender que quieren arrebatarle su 
gobierno, decidido a resistir, toma las pocas armas que tiene y se acuartela en el edificio de la delegación municipal junto con Mateo y otros empleados. Entre tanto afuera del edificio los acusadores se reagrupan con la intención de forzar a los otros a salir. Después de los primeros tiroteos y de las primeras muertes, de un lado y del otro se incorporan a la lucha grupos armados. De la parte de Ignacio se suman los muchachos de la Juventud Peronista, mientras que del lado de Suprino llegan los muchachos del Comando de Organización. Después de una noche de asesinatos y bombardeos de excrementos en la que Ignacio muere tras ser torturado brutalmente, amanece y el pueblo vuelve a una presunta normalidad.

La segunda novela de que nos ocuparemos es Cuarteles de Invierno (1980). La acción se desarrolla en plena dictadura militar. Los protagonistas son dos artistas: el primero, Galván, es un cantante de tango, mientras que el segundo, Rocha, es un boxeador. Ambos están en el final de su carrera y llegan a Colonia Vela contratados por los militares para animar el festejo del aniversario del pueblo. Debido a pequeñas rebeldías, tales como no ir a la iglesia y negarse a firmar un autógrafo a un miembro de los Servicios de Inteligencia, a Galván se le cancela el contrato acusándolo de ser un disidente. Entre tanto se descubre que la pelea de Rocha está arreglada de antemano. Al enterarse, el boxeador decide quedarse a pelear igualmente para rescatar su honor delante de Marta, la chica de la que está enamorado y Galván, animado por un sentimiento de solidaridad, le propone ser su manager. La pelea, como estaba previsto, se convierte en una carnicería y Rocha queda al borde de la muerte. La novela termina con Galván transportando a Rocha a la estación para llevarlo a Buenos Aires y de esta forma poder recibir la atención médica que se le ha negado en Colonia Vela.

En ambas novelas Soriano se nutre y reescribe convenciones genéricas del cine western.

De acuerdo con Adriana Spahr, "los personajes de Soriano no presentan ninguna característica que los distinga en su individualidad, pudiéndoselo ver de esta forma como representantes de un determinado grupo o sector dentro de la población argentina" (Spahr, 2006: 40). La caracterización que hace Soriano obedece esencialmente a dos criterios: el estético y el funcional. Los personajes se señalan y se reconocen por sus características físicas (el grandote, el morocho, el gordo, el petiso) o por sus funciones dentro de la historia (el intendente, el cantante, el milico, el gorila). Este sistema se utiliza también a la hora de caracterizar a los protagonistas. De Rocha, el boxeador, se dice que: "(Era) un tipo que andaría por los dos metros y los cien kilos con una cara tristona [...] que al caminar apoyaba los pies contra el asfalto como si viniera aplastando hormigas" (Soriano, 1982: 7-10). Desde el principio se le atribuyen apodos que se utilizarán a lo largo de toda la novela, él será alternativamente "el grandote", "el boxeador" o inclusive "King Kong", con clara referencia 
al célebre gorila del cine. La proliferación de los epítetos que muy a menudo se sustituyen a los nombres propios es una característica que se encuentra también en varias películas pertenecientes al género western, en particular a la variante conocida como Spaghetti western, pensemos por ejemplo en el título de la famosísima película de Sergio Leone de 1966 El bueno, el feo y el malo.. Esta afirmación encuentra confirmación en las palabras de Douglas Pye, quien habla en estos términos de los personajes de Río Bravo, la película de Howard Hawks de 1959:

The abstraction here is in the characters and action. The main characters are readily identifiable genre types characterized in largely conventional ways: the drunk, the smiling killer, the unbending sheriff. Their presentation is [...] unambiguous and familiar (for the public) [...] (since) the opening moments of the film" (Pye, 2003: 213).

Soriano recurre muy a menudo a la caracterización de sus personajes mediante repertorios extraverbales claramente inspirados en el cine, es el caso del ya citado King Kong, pero este no es el único. Los ejemplos a lo largo de las novelas son numerosos. Entre ellos el de un milico al que se le llama todo el tiempo Gary Cooper. Aquí, el hecho de utilizar el nombre de un célebre intérprete de películas western, parece querer explicitar la influencia de este modelo en la novela.

Según Stefano Ghislotti "Nell'assiologia tradizionale del western amico e nemico sono categorie nettamente distinte e chiaramente sentite dal pubblico" (Ghislotti, 2008: 162). Esta opinión es compartida por Suzanne Liandrat, quien al hablar del western dice: "le méchant se signale comme tel au spectateur par des détails qui ne trompent pas: battre un enfant o un chien [...] sont autant de traits qui suffisent à identifier le scélérat" (LiandratGuigues, 1993: 20). En las novelas de Soriano la repartición del universo narrativo entre buenos y malos se establece desde las primeras páginas. En Cuarteles de Invierno esta repartición es particularmente evidente. Desde la primera escena en la estación de Colonia Vela, se establece el conflicto entre los protagonistas y los militares que representan el poder en el pueblo. Estos, con sus palabras arrogantes y sus armas amenazadoras, se ganan desde el principio el papel de "malos" de la película. En su presentación, el "detalle que no falla" (del que hablaba Liandrat a propósito del western) es el hecho de que "apunten a Rocha la espalda". Apuntar a alguien por la espalda no solo es una actitud violenta sino también cobarde, que parece aún más condenable ya que el boxeador es presentado desde el principio como una especie de gigante bueno. Si como afirma Stefano Ghislotti: "nell'universo manicheo del western parteggiare per l'amico significa essere contro i nemici" (Ghislotti, 2008: 162), en Cuarteles de Invierno acontece algo parecido: la amistad entre Rocha y Galván se concreta en la resistencia común frente a las injusticias llevadas a cabo por los militares. Se necesita poco para que a los dos se los considere "compinches", 
basta con que uno de los protagonistas defienda al otro cuando Gary Cooper lo insulta públicamente en el bar.

Algo parecido acontece en No habrá más penas ni olvido donde la amistad con Mateo, el presunto infiltrado, coloca a Ignacio Fuentes en el bando de los "subversivos", en contra de Suprino y de los militares enviados de Tandil.

En muchas películas western el motor de la acción es una afrenta o una injusticia que provoca la reacción de los personajes del bando "ofendido", es así que se produce un conflicto. Este casi siempre se manifiesta a través de un enfrentamiento violento entre los rivales y tiene como objetivo la venganza de la afrenta inicial. Este esquema se encuentra también en las tramas de muchas novelas de Soriano o en algunos episodios secundarios en ellas contenidos.

Es el caso de Cuarteles de Invierno donde el primer conflicto entre los protagonistas y los militares se produce porque Galván se niega a firmar un autógrafo y su actitud, interpretada como una afrenta por los militares, desencadena todo el conflicto posterior que llevará a la cancelación de su contrato y a los enfrentamientos violentos del final.

De acuerdo con Croce los personajes de Soriano "parecen salidos de una historieta cuyo dibujante hubiera exagerado los trazos" (Croce, 1998: 52-53). Habrá que preguntarse, sin embargo, ¿qué es lo que los define como caricaturas?

Una respuesta se halla en el desfase que se establece entre la presentación que nos ofrece de ellos el narrador y su actitud a lo largo de la historia. Con frecuencia en las descripciones iniciales se hace hincapié en la pertenencia ideológica de ciertos personajes y en la entereza moral que los caracteriza, sin embargo los discursos que dichos personajes pronuncian y la conducta que adoptan en la historia parecen desmentir todo el tiempo estas afirmaciones iniciales. Es así como Mateo es acusado de ser un infiltrado marxistacomunista, aun si lo único que hace "es cobrar los impuestos y arreglar los papeles de la oficina" (Soriano, 1983: 20). Su escasa conciencia política se muestra claramente cuando, ignorando la razón por la cual lo quieren echar le dice a Ignacio: "Pero si yo siempre fui peronista..., nunca me metí en política" (Soriano, 1983: 32). La ironía nace del hecho de que los personajes parecen no estar a la altura de las misiones que se les encargan. Emblemático es el caso de los muchachos de la Juventud Peronista a quienes Ignacio les encarga lanzar el ataque decisivo a las fuerzas de derecha atrincheradas en la plaza, y ellos, sin darse cuenta de la urgencia de la situación, contestan que no pueden salir porque están en asamblea permanente. Después de todo, esta actitud tampoco sorprende mucho, puesto que lo único que se había dicho de ellos para dar prueba de su heroísmo, es que arreglaron los bancos de la escuela y limpiaron la sala de primeros auxilios.

También la unión de los personajes en bandos, perdiendo todas las connotaciones morales e ideológicas que la caracterizaban en el western, parece en Soriano completamente 
casual. En No habrá más penas ni olvido, Ignacio recluta a sus compañeros de aventura al azar, simplemente porque se encontraban en el edificio de la municipalidad cuando este último decide ocuparlo. Ellos, por otra parte, aceptan participar en la empresa sin tener bien claro lo que está pasando (Soriano, 1983: 33).

Héctor Freire, al hablar de los personajes arquetípicos del western, subraya la contraposición entre el bien y el mal característica de este género, cuyas películas se concluyen siempre con la victoria del primer elemento sobre el segundo:

Innumerables films hollyoodenses de "cowboy" repiten hasta el cansancio la serie de arquetipos y sus variaciones argumentales de este mito modelo: el héroe es [....] blanco, recto, respetuoso y elegante. Defensor de la justicia, valiente y desinteresado. Y por supuesto siempre triunfa. El malo, [...] por su parte viste de negro, destruye sin causa, es egoísta y está condenado a morir (Freire, 2009: 14$15)$.

En las novelas de Soriano, en cambio, los "buenos" no triunfan e inclusive su actitud a lo largo de la historia parece desmentir los valores enunciados por Freire: en No habrá más penas ni olvido, por ejemplo, el sargento García acepta acompañar a Ignacio en su resistencia solo porque este le promete un aumento de sueldo. Si como dice Georges-Albert Astre "le western accomplit donc une fonction moralisatrice élémentaire, et dispense alors une vue très "optimisante" des rapports humains [...] (où) les bons sentimentssont de règle: l'univers westernien est celui de la générosité, de la gratitude, du courage désintéressé" (Astre, 1973: 151); en el mundo narrativo de Soriano, en cambio, el poder ya no es depositario de valores positivos, no hay coraje desinteresado y todo sistema de valores morales se ha derrumbado. La lucha es tan absurda como desesperada. Es por eso que respecto al western, cambian los efectos del conflicto que aquí ya no sirve para restablecer la justicia sino para demostrar que no hay lugar para ningún heroísmo. Prueba de eso es el hecho de que las tramas siempre se concluyen con el fracaso del bando de quienes al principio habían sido identificados como los "buenos".

Según Delgado-Costa, en la construcción de las escenas violentas, Soriano se inspiraría esencialmente del modelo de las comedias slapstick, género que tuvo unas de sus mejores expresiones en las comedias protagonizadas por Laurel y Hardy. Dice DelgadoCosta "(en Soriano como) en el repertorio clásico del Gordo y el Flaco, la violencia llega hasta la estupidez". Un ejemplo famoso de esta tendencia se encontraría, según él, en Battle of the Century (1927) donde aparece por primera vez "la escena apocalíptica de violencia en masa, en la que, en un caos ascendente, más de mil pasteles son arrojados" (DelgadoCosta, 2003: 68). De hecho, escenas de este tipo aparecen muy a menudo en las novelas de Soriano. Tanto las peleas de Marlowe y Soriano durante la noche de los Oscar en Triste, solitario y final como las batallas a golpes de corchos de botellas de champán que 
emprenden los diplomáticos de $A$ sus plantas rendido un león, confirman un parentesco entre la comicidad de Soriano y el modelo del slapstick. Sin embargo esta cercanía no invalida la hipótesis de que sus novelas sean una parodia del cine western. Al contrario, la refuerza puesto que las primeras parodias del género realizadas en ámbito cinematográfico fueron llevadas a cabo precisamente por estas comedias, cuyos esquemas narrativos retoma nuestro autor. Un ejemplo podría ser WayOut West, la película de James Horne de 1937 interpretada -quizá no por casualidad- por dos autores fetiche de Soriano: Stan Laurel y Oliver Hardy.

\section{De la pantalla a la realidad}

Si aceptamos la presencia de una actitud paródica en el tipo de transposición del modelo western operada por Soriano, habrá que preguntarse si esta parodia vehicula una evaluación crítica de la realidad histórica que aparece en las novelas. En el caso de No habrá más penas ni olvido y Cuarteles de invierno la que se plantea es una relación entre la reescritura del género western y la sociedad argentina de los setenta, trasfondo histórico de las dos novelas. Ambas sociedades, tanto la que aparece en las películas western, como aquella en que Soriano desarrolla sus acciones, están dominadas por la violencia, violencia que se manifiesta, en la novela al igual que en el cine western, a través de la presencia continua de peleas, puñetazos y tiroteos. Lo que cambia es que en las novelas de Soriano los actos de violencia están desprovistos de toda justificación, jsiempre que se pueda considerar la violencia justificable en algún caso! Son tan absurdos que no parecen creíbles y adquieren un carácter tragicómico. Quizá este cambio se deba al hecho de que, mientras la violencia del cine western estaba legitimada por un sistema de valores que le confería el sentido de lucha contra la barbarie ${ }^{6}$; en el caso de Soriano la violencia no tiene explicación porque en Colonia Vela la gente ya no tiene nada por que luchar. Esta desconfianza generalizada que se encuentra en las novelas podría interpretarse como un reflejo del clima de decepción que se respiraba en Argentina tras el regreso del Peronismo en el 73. Según explica Adriana Spahr: "Contradictoriamente a lo que todos esperaban, la llegada del Peronismo estuvo marcada por una encarnizada conflagración entre los distintos sectores que conformaban ese amplio movimiento policlasista y multifacético en el plano ideológico" (Spahr, 2006: 54). En la novela lo que le agrega absurdidad al conflicto es justamente el hecho de que todos los personajes se proclamen peronistas. Este hecho encuentra un eco en las declaraciones de Spahr, quien cuenta "nos convertimos en espectadores de una violencia que no terminamos de comprender, más aun cuando los bandos en pugna se proclaman como pertenecientes al mismo partido político" (Spahr, 2006: 13).

6VéaseLeutrat, Jean Louis y Liandrat-Guigues, Suzanne (2007) Western(s). París: Klincksieck. 
En Cuarteles de invierno la violencia textual se vuelve el triste contrapunto de las violencias perpetradas por el gobierno militar durante los años de la dictadura. Los dos héroes son víctimas de este sistema y se encuentran perseguidos por los militares sin haber hecho nada por merecer este destino. Ambos llegan a Colonia Vela para ganar "unos duros" y su actitud frente a la política es de total indiferencia. El hecho de que Soriano haya elegido dos personajes de este tipo y no dos activistas se podría leer como la voluntad de denunciar las operaciones de detención masiva perpetradas por los militares antes y después del golpe. Estas incluyeron hombres y mujeres de todas las edades y de toda pertenencia social, muchos de los cuales no tenían ningún compromiso político real.

Podríamos concluir que la presencia del cine en la narrativa de Soriano, sin dejar de ser un homenaje al cine hollywoodense, es también y sobre todo una manera para hablar de la realidad política argentina. Su relectura de la tradición cinematográfica hollywoodense se configura entonces como una parodia consciente destinada a vehicular un pensamiento crítico sobre la sociedad argentina ${ }^{7}$. Esta hipótesis se puede aplicar a todos los textos narrativos de Soriano. Ya en Triste, solitario y final, como ha señalado José Delgado-Costa, aunque la acción acontece en California, no faltan las referencias a las violencias de la Argentina de los setenta. Su sombra aparece claramente en el episodio en que Marlowe y Soriano son brutalmente golpeados por la policía:

-Se les fue la mano -dijo el policía joven- estos dos están para el hospital. [...]

-Llévalos a dar un paseo, no podemos darle esto al fiscal.

El joven salió y regresó con dos hombres en ropa de calle.

-Apúrense, que no los agarre el amanecer.

Cargaron los dos cuerpos y por una puerta estrecha salieron al patio. Los echaron en el asiento trasero de un coche sin patente. [...] Veinte minutos más tarde tres hombres descargaban los cuerpos sobre una playa de Bay City (2008: 122).

Aunque el lugar en el que se abandonan los cuerpos es una célebre playa californiana, los hombres en ropa de calle, el coche sin patente y la hora de la operación nos permiten leer detrás de este episodio una referencia a la represión política en la Argentina de los años Setenta. En Triste, solitario y final Soriano realiza una parodia de la novela negra y es esta reescritura del género que le permite hablar de los conflictos de la California contemporánea y, a través de ellos, de la violencia de su país.

\footnotetext{
${ }^{7}$ Linda Hutcheon tras distinguir entre sátira y parodia recuerda la existencia de formas mixtas que combinan estos dos géneros. Una de ellas es la sátira paródica, un tipo de sátira que "apunta a un objeto fuera del texto pero utiliza la parodia como dispositivo estructural para llevar a cabo su finalidad correctiva" (Hutcheon, 1992: 185).
} 
En las últimas novelas $-A$ sus plantas rendido un león y Una sombra ya pronto serás- el blanco de la sátira será la Guerra de las Malvinas, la Argentina de la post-dictadura y la crisis económica y social que desembocará en el gobierno de Carlos Menem. En Una sombra ya pronto serás la crisis de valores y la desorientación que afecta a los personajes es la misma que experimentan muchos argentinos en los años ochenta, en particular los que, tras un exilio de casi diez años, tuvieron que empezar de cero en un país devastado por la inflacción y traumatizado por los horrores de la dictadura. Es esta Argentina, deformada pero siempre reconocible, la que aparece en Una sombra ya pronto serás, una sátira paródica en la que Soriano retrata con lucidez y mucho humor una época dificil de la historia reciente de su país.

Esto es, Soriano reescribe los grandes géneros del cine hollywoodense pero, al privar los personajes de sus atributos fundamentales o al alterar el contexto de sus acciones, los ridiculiza, transformándolos en héroes con aires quijotescos. En el caso del western, como en el de otros géneros, la desmitificación del héroe conlleva un cuestionamiento de los valores asociados al género, valores que ya no resultan aplicables a la Argentina en la que el autor ambienta sus novelas. El resultado es una reescritura que es también instrumento de sátira social y política. Es así como más allá del juego interartístico, detrás de aquella violencia "cinematográfica", aparece amenazadora la sombra de otra violencia, terriblemente más real, la que padeció Argentina antes y después del golpe militar del 76. 


\section{Referencias bibliográficas}

Altman, Rick (1984). "A Semantic/Syntactic Approach to Film Genre". Cinema Journal vol. 23, 3: 6-18. DOI: 10.237/1225093

Altman, Rick (2000). Los géneros cinematográficos. Barcelona: Paidós.

Astre, Georges-Albert y Hoarau, Albert Patrick (1973). Univers du western : les sources, les structures, les données permanentes, les significations. París: Seghers.

Barthes, Roland (1970). Mythologies. París: Éditions du Seuil.

Benveniste, Emile (1974). Problemas de lingüística general I. México: Siglo XXI.

Benveniste, Emile (1977). Problemas de lingüística general II.México: Siglo XXI.

Bettetini, Gianfranco (1975). Produzione del senso e messa in scena. Milano: Bompiani.

Casetti, Francesco (1980). "Le texte du film" VVAA, Théorie du film. Paris: Albatros.

Casetti, Francesco (2002). "Cinema, letteratura e circuito dei discorsi sociali". Perniola, Ivesole (ed.) Cinema e Letteratura: percorsi di confine. Venezia: Marsilio: 21-31.

Croce, Marcela (1998). Osvaldo Soriano. El mercado complaciente. Buenos Aires: Emilia Segotta.

Delgado-Costa, José (2003). Binarración y parodia en las primeras tres novelas de Osvaldo Soriano. Lewiston: E. Mellen Press.

Freire, Héctor J. (2009). El cine en su laberinto. Literatura, pintura, sociedad. Buenos Aires: Topía.

Ghislotti, Stefano (2008). "Una buona lezione. Scazzottate nel western classico". Rosso, Stefano. Le frontiere del Far West. Forme di rappresentazione del grande mito americano. Milano: Shake: 153-165.

Huerta-Floriano, Miguel Ángel (2005). Los géneros cinematográficos. Usos en el cine español (1994-1999). Salamanca: Universidad Pontificia.

Hutcheon, Linda (1981). "Ironie, satire, parodie. Une approche pragmatique de l'ironie".Poétique46: 140-155.

Hutcheon, Linda (1992). "Ironía, sátira, parodia. Una aproximación pragmática a la ironía". Silva, Hernán (ed.) De la ironía a lo grotesco. México: Universidad Autónoma Metropolitana Iztapalapa: 173-193.

Kaminski, Stuart (1994). American film genres. Dayton: Pfaun.

Leutrat, Jean Louis y Liandrat-Guigues, Suzanne (2007). Western(s). París: Klincksieck.

Liandrat-Guigues, Suzanne (1993). "Le western" Serceau, Michel (ed.) Panorama des genres au cinéma. Cinémaction 68. París: Télérama: 18-25. 
Marchese, Angeloy Forradellas, Joaquín (1994). Diccionario de retórica, crítica y terminología literaria. Barcelona: Ariel.

Metz, Christian (1977). "Histoire/discours (note sur deux voyeurismes)". Le signifiant imaginaire. Psychanalyse et cinéma. Paris : Union Génerale d'Editions.

Pérez Bowie, José Antonio (2008). Leer el cine: La teoría literaria en la teoría cinematográfica. Salamanca: Ediciones Universidad de Salamanca.

Pezzella, Mario (2004). Estética del cine. Madrid: A. Machado Libros.

Previtera, Roberta (en prensa). "Triste, solitario y final del cine negro a la literatura neopolicial" Sánzhez Zapatero, Javier y Martín Escribà, Álex (ed.) Actas del IX Congreso Internacional de Novela y Cine Negro.

Previtera, Roberta. "Escritura e imágenes de la carretera: la narrativa de Osvaldo Soriano". Diaspore. Quaderni di Ricerca 2 (2013): 101-109.

Pye, Douglas (2003). "The western (genres and movies)" Keith Grant, Barry (ed) Film genre reader III. Austin: University of Texas Press: 203-218.

Rojas Mix, Miguel (2006). El Imaginario. Buenos Aires: Prometeo.

Sklodowska, Elzbieta (1991). La parodia en la nueva novela hispanoamericana (19601985). Amsterdam-Philadelphia: John Benjamins Publishing Company.

Soriano, Osvaldo (2008). Triste, solitario y final. Buenos Aires: Booket.

Soriano, Osvaldo (1983). No habrá más penas ni olvido. Buenos Aires: Bruguera.

Soriano, Osvaldo (1982). Cuarteles de invierno. Barcelona: Bruguera.

Soriano, Osvaldo (1994). Una sombra ya pronto serás. Buenos Aires: Sudamericana.

Soriano, Osvaldo (1986). A sus plantas rendido un léon. Buenos Aires: Sudamericana.

Soriano, Osvaldo (1992). El ojo de la patria. Buenos Aires: Sudamericana.

Spahr, Adriana (2006). La sonrisa de la amargura. La historia argentina a través de tres novelas de Osvaldo Soriano. Buenos Aires: Corregidor.

VVAA (1992). New vocabularies in film semiotics: structuralism, post-structuralism, and beyond. Londres: Sightlines.

\section{Filmografía}

Allen, Woody (1966). What's up, tiger Lily? EE.UU: Allen,Woody y MihashiTatsuya.

Altman, Robert (1973). The long goodbye. EE.UU: Gould, Elliott y Van Pallandt, Nina.

Eastwood, Clint (1992). Unforgiven. EE.UU: Ackman, Gene y Freeman, Morgan.

Hawks, Howard (1946). The big sleep. EE.UU: Humphrey Bogart y Lauren Bacall. 
Hawks, Howard (1959). Rio Bravo. EE.UU: Wayne, John y Martin, Dean.

Hill, Walter (1980). The long riders. EE.UU: Keach, James y Carradine, David.

Hopper, Dennis (1969)Easy Rider. EE.UU: Hopper, Dennis y Fonda, Peter.

Kubrick, Stanley (1964).Dr Strangelove. Reino Unido: Sellers, Peter y Scott, George.

Leone, Sergio (1966). Il buono, il brutto, il cattivo. Italia: Eastwood, Clint y Wallach, Eli.

Montgomery, Robert (1947). Lady in the lake. EEUU: Montgomery, Robert y Totter, Audrey.

Penn, Arthur (1967). Bonnie and Clyde. EE.UU: Beatty, Warren y Dunaway, Faye.

Reis, Irving (1942). The falcon takes over. EE.UU: Sanders, George y Bary Lin.

Richards, Dick (1975). Farewell my lovely. Reino Unido: Mitchum, Robert y Rampling, Charlotte.

Scott, Ridley (1991). Thelma and Louise. EE.UU: Davis, Geena y Sarandon, Susan.

Winner, Michael (1978). The big sleep. Reino Unido: Mitchum, Robert y Miles, Sarah. 